convenient for the defendant to appear in Maryland. He was represented by an agent in the United States, and only documentary evidence was needed from Panama. The contract provided that Maryland law should govern its construction and that performance was subject to approval by several agencies of the United States government. Finally, it is worth noting that the defendant voluntarily agreed to perform the contract in Maryland, and he in fact carried out some of the obligations before breach.

The Maryland court expressly limited its decision to the facts before it. The mere mailing of an acceptance in Maryland would have been insufficient, in the court's view, to establish jurisdiction. The decision does not establish any certain criteria for the determination of jurisdiction over non-residents; yet, lack of certainty is not new in this field. Practical concern for notice, convenience and adequate chance to defend are more appropriate and no less certain than attempting to establish the "doing of business" and corporate presence.

\title{
EFFECT OF 1404(a) TRANSFER ON FEDERAL JURISDICTION OVER FOREIGN CORPORATIONS
}

International Shoe Co. v. Washington ${ }^{1}$ may be read as establishing two requirements for obtaining jurisdiction over a foreign corporation which has not consented to suit in the forum: (1) there must be physical activity within the state of more than incidental nature, and (2) it must not be grossly unfair to force the corporation to defend the suit in the forum. The second requirement necessitates "an estimate of the inconveniences" to the defendant, and is therefore closely related to Section 1404(a) of the Federal Judicial Code which provides that: "For the convenience of parties and witnesses, in the interest of justice, a district court may transfer any civil action to any other district or division where it might have been brought." "Judge Learned Hand has even gone so far as to state that the two issues are "certainly indistinguishable." $\mathrm{A}$ curious

${ }^{1} 326$ U.S. 310 (1945).

2 Ibid., at 317.

362 Stat. 937 (1948), as amended, 28 U.S.C.A. $\$ 1404$ (a) (1952).

4 Kilpatrick v. Texas \& P. Ry. Co., 166 F. 2d 788 (C.A. 2d, 1948). Judge Hand was speaking of the doctrine of forum non conveniens rather than of Section 1404(a). However, the considerations underlying both doctrines are identical. The reviser of the United States Code says that Section 1404(a) "was drafted in accordance with the doctrine of forum non conveniens." Reviser's note, 28 U.S.C.A. \$ 1404 (1950). This interpretation has been described by the Supreme Court as "obviously authoritative." United States v. National City Lines, 337 U.S. 78, 81 (1949). There have been some dicta to the contrary: see Jiffy Lubricator Co. v. Stewart-Warner Corp., 177 F. 2 d 360 (C.A. 4th, 1949); Headrick v. Atchison Topeka \& S.F. Ry. Co., 182 F. 2 d 305 (C.A. 10th, 1950); All States Freight v. Modarelli, 196 F. 2d 1010 (C.A. 3d, 1952), but these cases have been concerned with the difference between transfer and dismissal rather than with the considerations underlying the doctrines. For an extensive and comprehensive discussion of the relation between Section 1404(a) and the doctrine of forum non conveniens, consult Currie, Change of Venue and the Conflict of Laws, $22 \mathrm{U}$. of Chi. L. Rev. 405 (1955). 
paradox appears. If a non-consenting foreign corporation has a legitimate objection to the forum in which suit is brought, a transfer to a more convenient forum removes the basis of the corporation's objection. Yet, if Judge Hand's statement is correct, the court, when it orders transfer, is at the same time admitting that it lacks jurisdiction under International Shoe.

As a matter of black-letter law, when a court is faced with the alternative motions of dismissal for lack of jurisdiction under International Shoe and transfer under Section 1404(a), it should consider the jurisdictional question first. ${ }^{5}$ Therefore the "inconveniences" should be estimated for the purpose of determining whether the suit should be dismissed under the requirements of International Shoe. If the answer is in the affirmative the possibility of transfer should not be considered, since the exercise of discretion under Section 1404(a) presumes jurisdiction in the transferring court. ${ }^{6}$ The conclusion appears to be that transfer is not possible in suits in which International Shoe is determinative of the court's jurisdiction since dismissal is indicated whenever the motion to transfer would otherwise be granted.

Section 1404(a) is a modern innovation which codifies the doctrine of forum non conveniens but substitutes the milder solution of transfer for the dismissal required by that doctrine. ${ }^{7}$ It would be unfortunate to deny the advantages of this eminently reasonable provision to parties in suits against foreign corporations because of the second requirement of International Shoe.

The problem is small in scope; possible conflict appears only in cases against foreign corporations which have not consented to suit in the state and have not waived the question of jurisdiction by failing to dismiss on that ground. The courts that have considered this problem have not adopted a consistent and coherent approach to the difficulties presented: cases against foreign corporations have been transferred without a careful analysis of the effect that transfer has on the court's jurisdiction. ${ }^{8}$ The problem presented raises fundamental questions about the meaning of International Shoe and the scope of Section 1404(a).

5 E. K. Carey Drilling Co. v. Murphy, 113 F. Supp. 226 (D. Colo., 1953); Stickney v. Wilt, 23 Wall. (U.S.) 150 (1874); Mail Company v. Flanders, 12 Wall. (U.S.) 130 (1870).

6 Petroleum Financial Corp. v. Stone, 116 F. Supp. 426 (S.D. N.Y., 1953); Burns v. Chubb, 99 F. Supp. 581 (E.D. Pa., 1951).

7 "There seems to be no doubt, in view of the reviser's note, that the intent of Congress in enacting Section 1404(a) was to adopt legislatively the doctrine of forum non conveniens. While such codification in itself can be considered a benefit, it seems to us that the primary intention of Congress was to work a distinct improvement in the operation of the rule by making unnecessary the cumbersome and hazardous procedure of dismissing the action in the original court and instituting a new action in another district." Rogers v. Halford, $107 \mathrm{~F}$. Supp. 295, 297 (E.D. Wis., 1952).

${ }^{8}$ Cf. Magnetic Engineering \& Mfg. Co. v. Dings Magnetic Separator Co., 86 F. Supp. 13 (S.D. N.Y., 1949). The defendant moved for transfer under Section 1404(a) but did not move to dismiss for want of jurisdiction. After deciding that the defendant corporation was physically within the jurisdiction, the court said, "Although the defendant comes within the literal language of the venue statutes, it still remains to be determined whether this forum 
I

The problem would disappear if a greater inconvenience is required for dismissal under International Shoe than for transfer under Section 1404(a). Theoretically, the inconvenience to the defendant could be such that the court would order transfer, but might not be serious enough to amount to a denial of due process. The presence of such a theoretical distinction finds support in judicial dicta. The courts which state that such a distinction exists, however, have not attempted to apply it. In Pan American Airways v. Consolidated Vultee Aircraft Corp., ${ }^{9}$ for example, the court said:

As a general principle, I feel that due process may admit of greater inconveniences than those which would sustain a plea of forum non conveniens. In this case the defendant seeks . . . a transfer . . . under the plea of forum non conveniens. So, because of the affinity of the rationale of this plea and the considerations in the second factor of "presence," the court will consider them together. ${ }^{10}$

And in Latimer v. S/A Industrias Reunidas F. Matarazzo, ${ }^{11}$ Judge Hand states that "[i]t may still be true that in theory the issue as to jurisdiction is different from that as to forum non conveniens; ... for practical purposes it will be enough if the second factor in 'presence' be tried out along with the plea of forum non conveniens." "12 Not only have the courts failed to apply such a distinction, but some of them have implied that it does not exist. Courts tend to equate both the "estimate of the inconveniences" required by International Shoe and the similar estimate required by Section 1404(a) to the older doctrine of forum non conveniens. ${ }^{13}$

would be so inconvenient to defendant as to trespass on its right of due process." Ibid., at 16. The court considered the matter of convenience and decided, "For all of the foregoing reasons the Court concludes that there does not exist here that second element in 'presence' necessary to subject the defendant corporation to suit here in this action." Ibid., at 17. The court decreed, however, that "The motions to transfer are granted and the whole action ... will be transferred to the Eastern District of Wisconsin." Ibid., at 17.

In Schiller v. Mit-Clip Co., 180 F. 2d 654 (C.A. 2d, 1950), the defendant corporation had moved to dismiss because it had never done business in the district. The district judge did not dismiss but transferred the case sua sponte to another forum under 63 Stat. 101 (1949), as amended, 28 U.S.C.A. $\$ 1406$ (a) (1952). This section permits the transfer of an action when venue is improperly laid to a district where it could have originally been brought if it be in the interest of justice. The transfer was ordered notwithstanding that the defendant was not "present" within the jurisdiction and had asked for dismissal. The court of appeals also found that the defendant's activity in the jurisdiction was "utterly insufficient to give the district court any power to proceed against it." Schiller v. Mit-Clip Co., supra, at 655 . However, the court refused to review the order on the appeal of the plaintiff.

987 F. Supp. 926 (S.D. N.Y., 1949).

10 Tbid., at 929.

11175 F. 2d 184 (C.A. 2d, 1949).

12 Ibid., at 186. (Italics added.) This was an action against a Brazilian corporation where there was no other district in the United States to which the action could conveniently have been transferred.

${ }^{13}$ See notes 4 supra, and 30 infra. 
Further, considerable inconvenience is necessary before a court will order transfer under Section 1404(a). The plaintiff is granted wide discretion in the choice of forum, and that "choice should not lightly be set aside." balance of convenience" 15 in the defendant's favor is insufficient. To grant transfer only in cases of "actual hardship"16 causes the estimate of inconvenience under 1404(a) to become virtually identical to that under International Shoe. Even if a fine line remains between the two, it is too obscure to be of practical use.

Another possible solution would be to base the measure of unfairness appropriate to a plea for transfer on pragmatic considerations of actual inconvenience, and the measure of unfairness under International Shoe on facts conventionally considered in determining jurisdictional "power" over the defendant. Factors considered important under Section 1404(a) include the location of witnesses and the cost of transporting them, ${ }^{17}$ the location of evidence appropriate for jury view, ${ }^{18}$ the location of books and records, ${ }^{19}$ and the judge's familiarity with the state law which is to be applied under conflicts principles. ${ }^{20} \mathrm{It}$ is undeniable that many courts when applying International Shoe do not appear to be considering such factors. Their analysis involves only the extent of corporate activities within the state-the presence of an agent as contrasted with an independent contractor, ${ }^{21}$ the percentage of the corporation's business done within the

${ }^{14}$ Dairy Industries Supply Ass'n v. La Buy, 207 F. 2d 554, 558 (C.A. 7th, 1953). Accord: Sun Oil Co. v. Lederle, 199 F. 2d 423 (C.A. 6th, 1952); Markantonatos v. Maryland Drydock Co., 110 F. Supp. 862 (S.D. N.Y., 1953).

15 Judge Learned Hand concurring in Ford Motor Co. v. Ryan, 182 F. 2d 329, 332 (C.A. 2d, 1950). Accord: International Union v. United Electrical, R. \& M. Workers, 192 F. 2d 847 (C.A. 6th, 1951).

${ }^{16}$ Mazinski v. Dight, 99 F. Supp. 192, 194 (W.D. Pa., 1951). See also Nicol v. J. C. Penney Co., 97 F. Supp. 83,85 (E.D. Mich., 1951).

${ }^{17}$ Nicol v. Koscinski, 188 F. 2d 537 (C.A. 6th, 1951).

18 Bounds v. Streckfus Steamers, Inc., 89 F. Supp. 242 (D. Del., 1950).

${ }^{19}$ Lehman v. Napier, 101 F. Supp. 313 (S.D. Iowa, 1951).

${ }^{20}$ Cinema Amusements v. Loew's, Inc., 85 F. Supp. 319 (D. Del., 1949). Other factors that have been considered in connection with 1404(a) are: possibility of prejudice where the action has been instituted, Caldwell v. Crowell-Collier Pub. Co., 83 F. Supp. 331 (N.D. Fla., 1949); the pendency of another action between the same parties concerning related matters in the transferee forum, Aircraft Marine Products v. Burndy Engineering Co., 96 F. Supp. 588 (S.D. Cal., 1951); Christopher v. American News Co., 176 F. 2d 11 (C.A. 7th, 1949). The congestion of the docket of the transferor or transferee courts is a factor which is often submitted as evidence for or against transfer. The courts have apparently disagreed on whether Section 1404 (a) embraces this consideration or not, but most courts do consider it in appropriate cases. "The convenience of the court considering transfer or of the court to which transfer is sought is not an allowable standard or criterion except as it may be embraced in the term in the interest of justice." " Brown v. Insurograph, Inc., 85 F. Supp. 328, 329 (D. Del., 1949). A discussion of this point may be found in 51 Mich. L. Rev. 298 (1952), noting Oritz v. Union Oil Co., 102 F. Supp. 492 (S.D. N.Y., 1952). Consult also note, 52 Mich. L. Rev. 452 (1953).

${ }^{21}$ Robbins v. Benjamin Air Rifle Co., 209 F. 2d 173 (C.A. 5th, 1954); MicCarley v. Foster Milburn Co., 93 F. Supp. 421 (W.D. N.Y., 1950). 
state, ${ }^{22}$ maintenance of a bank account, ${ }^{23}$ the domestic office address appearing in magazines published by the defendant, ${ }^{24}$ the maintenance of an office in the district, ${ }^{25}$ and the like. ${ }^{26}$ But since the courts often do not distinguish between the first and second requirements of International Shoe, it is impossible to determine whether they limit the meaning of "conveniences" described in the second requirement to the jurisdictional facts considered under the first requirement of "minimum contacts," or whether the second requirement is being ignored.

Certain phrases in the International Shoe decision tend to support the view that the "estimate of the inconveniences" relates only to the facts on which the requirement of "contacts" is based. The Court said: "due process requires only that in order to subject a defendant to a judgment in personam, if he be not present within the territory of the forum, he have certain minimum contacts with it such that the maintenance of the suit does not offend 'traditional notions of fair play and substantial justice." ${ }_{27}$ On the other hand, another statement in the case seems to indicate that the conveniences relate to factors much broader than the minimal contacts of the first requirement:

Those demands [of due process] may be met by such contacts of the corporation with the state of the forum as make it reasonable, in the context of our federal system of government, to require the corporation to defend the particular suit which is brought there. An "estimate of the inconveniences" which would result to the corporation from a trial away from its "home" or principal place of business is relevant in this connection. ${ }^{28}$

There are many indications that the courts consider the nature of the second requirement of International Shoe, and the facts that are relevant thereunder, to be essentially similar to those under Section 1404(a). Relevant here are the cases which have considered the issues of fairness under both International Shoe

${ }^{22}$ Mississippi Wood Preserving Co. v. Rothschild, 201 F. 2d 233 (C.A. 5th, 1953).

${ }^{23}$ French v. Gibbs Corp., 189 F. 2d 787 (C.A. 2d, 1951).

${ }^{24}$ Consolidated Cosmetics v. D-A Publishing Co., 186 F. 2d 906 (C.A. 7th, 1951).

${ }^{25}$ Lasky v. Norfolk \& W. Ry. Co., 157 F. 2d 674 (C.A. 6th, 1946).

${ }^{26}$ Other considerations relating to jurisdiction over foreign corporations include: owning majority stock in a domestic corporation, Steinway v. Majestic Amusement Co., 179 F. 2d 681 (C.A. 10th, 1950); whether or not a wholly-owned subsidiary in the state is merely a dummy corporation, In Re Grand Jury, 72 F. Supp. 1013 (S.D. N.Y., 1947); regular participation in a trade show within the state, Schmikler v. Petersime Incubator Co., 177 F. 2d 983 (C.A. 1st, 1949). One consideration, the situs of the cause of action, appears at first glance to be considered under both 1404(a) and International Shoe situations. In a sense, this is true. However, completely different aspects of this factor are considered in each motion. Under 1404(a), the situs of the cause of action may be important only insofar as it relates to the whereabouts of witnesses. Consult, e.g., McKeen v. Union Pac. R. Co., 111 F. Supp. 876 (W.D. Mo., 1953); Tankel v. Seiberling Rubber Co., 95 F. Supp. 987 (N.D. Cal., 1951). Under International Shoe, the situs of the cause of action is important only so far as it evidences a physical intrusion or absence of the defendant within the state. E.g., Perkins v. Benguet Consolidated Mining Co., 342 U.S. 437 (1952); Johns v. Bay State Abrasive Products Co., 89 F. Supp. 654 (D. Md., 1950). Consult also comment, 22 U. of Chi. L. Rev. (1955).

27326 U.S. 310, at 316 (1945). (Italics supplied.)

28 Ibid., at 317. 
and 1404(a) together, apparently feeling them to be alike. ${ }^{29}$ Furthermore, several courts have equated the "estimate of inconveniences" under International Shoe to the doctrine of form non conveniens. ${ }^{30}$

\section{II}

Some courts have indicated that the possibility of transfer under Section 1404(a) should be considered as a substitute for the second requirement of $I n$ ternational Shoe. They have tended to ignore the "estimate of inconveniences" and to concentrate on the "minimum-contacts" requirement of International Shoe as determinative of jurisdiction. In Kendrick v. Seaboard Air Line R.R., ${ }^{31}$ Judge Ganey said: "It would seem that the ... disconnection between the alleged obligation or liability with a defendant's local activities, inconvenience to it or the unseasonableness of requiring it to defend the particular action in the forum are factors which no longer have any bearing on the question of jurisdiction over its person in view of Section 1404(a) of Title 28, U.S.C., permitting change of venue." 32 Similarly, in the Latimer case, after discussing Gulf Oil Co. v. Gilbert ${ }^{33}$ and Koster v. (American) Lumbermens Mutual Casualty Co. ${ }^{34}$ (establishing the doctrine of forum non conveniens in the federal courts), Judge Hand said, "These decisions answer any constitutional objection to dispensing altogether with the second factor in 'presence." ",35

Justice Black adopted an even more liberal position in his dissent in Polizzi ข. Cowles Magazines, Inc..$^{36}$ The case was instituted as a result of an article published by Look magazine describing Polizzi as one of the ring-leaders of a nationwide crime syndicate. Polizzi, a resident of Florida, sued Cowles Magazines, an Iowa Corporation, for libel in a Florida state court. The defendant removed, and moved to dismiss for want of jurisdiction. The district court held, and the

${ }^{29}$ Latimer v. S/A Industrias Reunidas F. Matarazzo, 175 F. 2d 184 (C.A. 2d, 1949); Pan American Airways v. Consolidated Vultee Aircraft Corp., 87 F. Supp. 926 (S.D. N.Y., 1949).

${ }^{30}$ Kilpatrick v. Texas \& P. Ry. Co., 166 F. 2d 788 (C.A. 2d, 1948); Healing v. Isbrandtsen Co., 109 F. Supp. 605 (S.D. N.Y., 1952); Insurance Co. of North America v. Lone Star Package Car Co., 107 F. Supp. 645 (S.D. Tex., 1952); Ronson Art Metal Works v. Brown \& Bigelow, 104 F. Supp. 716 (S.D. N.Y., 1952); Goldstein v. Chicago R. I. \& P. R. Co., 93 F. Supp. 671 (W.D. N.Y., 1950); Latimer v. S/A Industrias Reunidas F. Matarazzo, 175 F. 2d 184 (C.A. 2d, 1949).

$$
\begin{aligned}
& 3198 \text { F. Supp. } 372 \text { (E.D. Pa., 1949). } \\
& 33330 \text { U.S. } 501 \text { (1947). } \\
& { }^{32} \text { Ibid., at } 373 . \\
& { }^{34} 330 \text { U.S. } 518 \text { (1947). }
\end{aligned}
$$

${ }^{35} 175$ F. 2d 184, 186 (1949). In Cooke v. Kilgore Mfg. Co., 105 F. Supp. 733, 738 (N.D. Ohio, 1952), the court said, "Inasmuch as considerations of convenience are relevant in determining jurisdiction of a foreign corporation, it should be noted that Section 1404(a) of Title 28 U.S.C., enacted as part of the revised venue act of 1948, now affords a remedy to a corporate defendant against being compelled to defend an action in a jurisdiction remote from its commercial domicile, where maintenance of the suit there would be oppressively inconvenient and unjust." In French v. Gibbs Corp., 189 F. 2d 787, 790 (C.A. 2d, 1951), Judge Hand said, "[G]iven any continued local activities the strict requirement of 'presence' is satisfied; and ... the rest is a matter of more or less.".

${ }^{36} 345$ U.S. 663 (1953). 
court of appeals agreed, that the defendant was not doing business in Florida under Section 1391(c) of the Federal Judicial Code. The Supreme Court reversed, holding that that section was a venue statute and did not affect the court's jurisdiction, and in any event did not apply to removal cases. The case was remanded to the district court to decide properly the question of jurisdiction. Justice Black, concurring in part and dissenting in part, vigorously took issue with the majority opinion:

This ... case goes back for reconsideration of the same old "doing business" question that has been hanging fire for three years. It took three years for Polizzi to get here and have the Court by-pass the "doing business" question this time. If he is lucky enough to get that question back here and decided for him in three more years, he may then look forward to the possibility of having a jury try his case sometime along about 1957.

I think this Court should here and now reject Cowles' dilatory contentions.... Whether cases are to be tried in one locality or another is now to be tested by basic principles of fairness, unless, as seems possible, this case represents a throwback to what I consider less enlightened practices. ...

But aside from what has been said, there is a new statute which gives an anachronistic flavor, a sort of irrelevance to all of Cowles' dilatory motions and arguments. I refer to 28 U.S.C. \$1404(a) which has codified the doctrine of forum non conveniens. . . . [T] he question Cowles has been raising from the beginning is: In what federal district court does the fair administration of justice require that this lawsuit be tried? This poses precisely the problem which the rule of forum non conveniens is designed to meet and solve. In the light of that rule I think we should ... direct the District Court in Florida to try this case at once, unless Cowles can show that court that it would be in the interest of justice to try the case in another district. But the Court refuses to discard old outdated concepts for the new rule of convenience and fairness. ${ }^{37}$

Even though Justice Black was satisfied that Cowles' contacts with the state of Florida were adequate to meet the first requirement of International Shoe, ${ }^{38}$ his statements may be read as a suggestion that neither requirement of International Shoe is indispensable in the federal courts in the light of Section 1404(a). The only important question is "fairness," and transfer would always be available to remedy any inequity. Lengthy jurisdictional litigation, as in the Polizzi case, does not accord justice. It is doubtful, however, whether the proposal will find favor with the courts. While the concept of jurisdiction is an elusive one, it has always included at least a modicum of the idea of physical power over the parties. ${ }^{39}$ If a plaintiff is allowed to bring suit where he cannot hope to remain,

${ }^{37}$ Ibid., at 669-71.

${ }^{38}$ Ibid., at 670 . "Under any of the concepts, old or new, I think Cowles was doing business in Florida.... These facts, together with others which $\mathrm{I}$ need not labor, show the frivolous nature of the 'doing business' question."

${ }^{39}$ "Historically the jurisdiction of courts to render judgments in personam is grounded on their de facto power over the defendant's person. Hence his presence within the territorial jurisdiction of a court was prerequisite to its rendition of a judgement personally binding upon him." International Shoe Co. v. Washington, 326 U.S. 310, 316 (1945). 
he may add an extra procedural step at will, and cannot help but confuse the issues.

It appears unnecessary to extend the conflicting rationales of International Shoe and Section 1404(a) to the point Justice Black suggests. The problems disappear if the second requirement of International Shoe is removed. Further, the reasoning underlying this solution is appealing. The first requirement of International Shoe represents the older jurisdictional concept of power; the second embodies the more modern ideal of fairness. In that case the Supreme Court found an opportunity to apply modern notions of fairness to the question of jurisdiction. The Court virtually enacted the doctrine of fornm non conveniens into a jurisdictional requirement for suit against non-consenting foreign corporations; when International Shoe was decided, Section 1404(a) had not been enacted, and the extent to which the doctrine of forum non conveniens was applicable in the federal courts was uncertain. ${ }^{40}$ But with transfer now available, there is an unnecessary duplication of that doctrine at two levels in the trial. The protection afforded by the second requirement of International Shoe is no longer necessary, and the "sensible and moderate device of transfer"41 should be the sole answer to a plea of serious unfairness.

If this suggestion is adopted, an interesting problem arises with respect to the removed case. For the purpose of defining the jurisdiction of state courts the second requirement of International Shoe cannot be dropped since Section 1404(a) is not available there. ${ }^{42}$ If a case is instituted in a state court and removed, the question whether transfer can cure a deficiency in the jurisdiction of the state court will have to be faced. An affirmative answer will run counter to the well-settled rule that the jurisdiction of the federal court on removal is derivative from that of the state court. ${ }^{43} \mathrm{~A}$ negative answer denies the parties

\footnotetext{
${ }^{40}$ It was only after Gulf Oil Corp. v. Gilbert, 330 U.S. 501 (1947), decided two years after International Shoe, that the doctrine of forum non conveniens was recognized as generally applicable in" the federal courts. Justice Black, dissenting, said, "Except in relation to the exercise of the extraordinary admiralty and equity powers of district courts, this Court has never before held contrary to the general principle that 'the courts of the United States are bound to proceed to judgment, and to afford redress to suitors before them, in every case to which their jurisdiction extends." "Ibid., at 513.

4l Currie, Change of Venue and the Conflict of Laws, 22 U. of Chi. L. Rev. 405, 437 (1955).

22 Pope v. Atlantic Coast Line R. Co., 345 U.S. 379, 384 (1953). The doctrine of forum non conveniens as applied by state courts conceivably might serve as a substitute for the second requirement of International Shoe. Judge Learned Hand thought that forum non conveniens, newly adopted in the federal system in 1947, could serve as the "estimate of the inconveniences" in place of the second requirement of International Shoe. See text at note 35 supra. In the state courts, however, the invocation of forum non conveniens would result in dismissal, as under International Shoe. Furthermore, since some states do not accept the doctrine, and in others its meaning is obscure and its application limited, little would be gained by such a substitution in the state courts. For a survey of the position of the doctrine among the state courts consult Barrett, The Doctrine of Forum Non Conveniens, 35 Calif. L. Rev. 380 (1947).
}

${ }^{13}$ Lambert Run Coal Co. v. Baltimore \& Ohio R. Co., 258 U.S. 377 (1922). Accord: Freeman v. Bee Machine Co., 319 U.S. 448 (1943). For a discussion of the effect of transferring a 
the advantages of Section 1404(a). In view of the broad language of Section 1404(a), and the cases which have held that 1404(a) does apply to removal cases as well as those instituted in a federal court, ${ }^{44}$ it may easily be decided that transfer would continue to apply to removal cases even though changes were made in the federal doctrine of jurisdiction over foreign corporations. ${ }^{45}$

The other problems in adopting such a suggestion do not appear to be insurmountable. The major difficulty lies in certain conventional ideas about "jurisdiction over parties," but these ideas have been under attack in recent years. The advantages in fairness and speedy administration of justice to be gained by the liberal application of Section 1404(a) should more than offset the difficulties involved in eliminating the second requirement of International Shoe and considering questions of inconvenience solely under the motion for transfer.

removal case on the doctrine of Erie Railroad Co. v. Tompkins, 304 U.S. 64 (1938), consult Braucher, The Inconvenient Federal Forum, 60 Harv. L. Rev. 908 (1947).

${ }^{44}$ Chicago, R. I. \& P. R. Co. v. Igoe, 212 F. 2 d 378 (C.A. 7th, 1954); Grivas v. Parmelee Transp. Co., 207 F. 2d 334 (C.A. 7 th, 1953); Stewart v. Atchison, T. \& S.F. Ry. Co., 92 F. Supp. 172 (E.D. Mo., 1949). These cases, of course, arise when the jurisdictional requirements in the state and federal courts are identical.

${ }^{45}$ Consult Freeman v. Bee Machine Co., 319 U.S. 448 (1943), which overcame a technical barrier when it allowed an amendment to the complaint under a federal law although the amendment could not have been made in the state court.

\section{MEDICAI SOCIETIES AND MEDICAL SERVICE PLANS-FROM THE LAW OF ASSOCIATIONS TO THE LAW OF ANTITRUST}

The American Medical Association and its affiliated organizations are the avowed advocates of solo, fee-for-service medical practice. The ethics promulgated during a long fight for better standards in the profession, especially when coupled with traditional concepts of professionalism, admit of little variation. In comparison to the accepted methods of practice, ${ }^{1}$ prepayment group-practice plans are almost heretic. Often organized by unions, industrial management, or other lay sponsors, they combine the insurance principle of prepayment with the benefits obtainable through groups of general practitioners and specialists working on other than a fee-for-service basis with fully equipped clinics at their disposal. $^{2}$

1 In an exhaustive comment on the AMA, the Yale Law Journal has analyzed organized medicine's methods of opposition to disapproved practices. There it is indicated that the power of the medical societies is such that coercion directed against physicians affiliated with disapproved plans can be an effective weapon. The American Medical Association: Power, Purpose, and Politics in Organized Medicine, 63 Yale L. J. 937 (1954).

${ }^{2}$ See generally, Hunt \& Goldstein, Medical Group Practice in the United States (U.S. Public Health Service Publication No. 77, 1951); Serbein, Paying for Medical Care in the United States (1950); George Baehr, M.D. (President and Medical Director of the Health Insur-

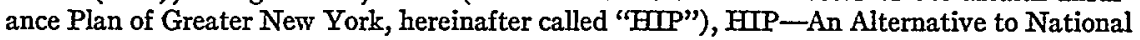

